\title{
Processos, conjunturas e narradores da história do Jornalismo
}

\section{Marialva Carlos Barbosa*}

MELO, José Marques de. História do jornalismo: itinerário crítico, mosaico

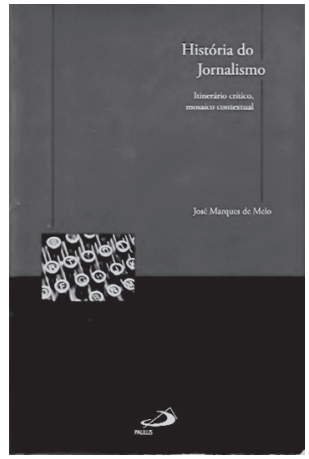
contextual. São Paulo: Paulus, 2012. 472p.

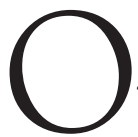
subtítulo do livro de José Marques de Melo História do Jornalismo: Itinerário crítico, mosaico contextual, que percorre uma história do Jornalismo no Brasil procurando reconstruir a lógica de constituição do campo a partir de três lugares privilegiados - denominados por ele processos, conjunturas e narradores - não poderia ser mais apropriado.

O livro se propõe a fornecer, sobretudo, aos jovens pesquisadores - diversas vezes referenciados na obra - um mosaico conceitual dos processos em que se desenvolveu a história da história do Jornalismo. Ou seja, como autores construíram conhecimento, pensamento, práxis, paradigmas etc. em ações de pesquisa e de reflexão da área que já possui mais de um século. É ainda preocupação de Melo situar os leitores em torno das principais problemáticas dessa história, indicando ampla bibliografia a partir

* Professora Titular de Jornalismo da Universidade Federal do Rio de Janeiro e do Programa de Pós-Graduação em Comunicação e Cultura da UFRJ, Rio de Janeiro- RJ, Brasil. Bolsista do CNPq. Vice-presidente da Intercom. 
da qual também ele foi construindo juízos de valor, interpretações, isto é, remontando um itinerário crítico em torno da constituição do Jornalismo como campo de saber.

Essa partilha do conhecimento adquirido em quase meio século como pesquisador e professor é mais do que uma característica do livro: é o ensinamento que está por detrás de cada linha, mostrando, sobretudo aos mais jovens, que o conhecimento não se faz sem doação e sem a percepção de que é a acumulação dos saberes que faz avançar um campo teórico.

A sensação que se tem ao ler cada trecho é que emanou do autor o desejo de partilhar muito do que leu, muito do que viveu, muito do que lutou para tornar o Jornalismo lugar de conhecimento reconhecido. Como movimento de síntese procurou, então, inventariar a história de alguns processos e conjunturas em que a pesquisa se desenvolveu e de oito narradores que elege como personagens privilegiados. É como se, ao final, dissesse: eis aqui uma síntese que revela não apenas o conhecimento, mas a vivência de quase meio século em torno dos estudos de uma disciplina.

Em vários momentos, o autor instiga os pesquisadores para que encontrem caminhos apropriados para o Jornalismo deste século 21. Com uma visão altamente otimista, não crê na "morte do Jornalismo" tão enfaticamente prevista por alguns, nem no desaparecimento dos velhos impressos. Acredita inexoravelmente na longevidade do Jornalismo pautada em dois caminhos principais: a construção de novos paradigmas para o Jornalismo popular e a ênfase na produção jornalística no ambiente multimídia em que as novas gerações nasceram.

Em relação ao primeiro aspecto, afirma que o Jornalismo deve se pautar pela lógica da inclusão de uma enorme parcela da população, que alcançando novos patamares de consumo, deve se configurar como público do Jornalismo diário. "Produzir um Jornalismo popular destinado às classes subalternas", nessa segunda década do século 21, trata-se de uma "contingência inexorável".

No que diz respeito ao segundo aspecto, alerta para os novos modos de expressão que acompanharam o ambiente multimídia no qual as novas gerações nasceram. Para o autor, não houve 
alteração na essência, motivação e fundamentos do Jornalismo. A necessidade da informação é cada vez mais crescente e transparente. Informação e opinião continuam a ser demandadas por todos, enfatiza. Esse novo ambiente que produziu uma metamorfose sensacional nos modos de fazer Jornalismo aponta para a necessidade de os núcleos de formação oferecerem conhecimentos sólidos ao futuro profissional que irá atuar junto a um público leitor que demandará cada vez mais por informação aprofundada e análise crítica. $O$ perfil do novo jornalista exige alguém com formação sólida suficiente para construir a notícia de maneira multidimensional, com suas implicações humanas, sociais, políticas econômicas e históricas.

Se o presente é uma preocupação constante do livro de José Marques de Melo porque no título elegeu como síntese a história do Jornalismo? A rigor, os processos do passado tão bem descritos pelo autor, ao lado das conjunturas que permitiram a ele percorrer uma história da construção da pesquisa histórica em Jornalismo são nutrientes suficientes para se pensar o mundo que denominamos contemporâneo. Só o entendimento de alguns debates fundamentais, das lógicas processuais da pesquisa, da formação da história do ensino dessa disciplina, entre outros percursos trilhados, permite a aguda reflexão sobre os caminhos do Jornalismo no século 21.

Na última parte do livro, denominada "Narradores", José Marques de Melo escolhe oito personagens que acredita terem tido papel relevante na construção da história do Jornalismo (ou da imprensa) no Brasil. Utilizando títulos conclusivos, como é comum na sua estilística que deixa antever sua formação profissional original, nomeia o precursor, o desbravador, o educador, o pesquisador, o scholar, o renovador, o inovador e a sucessora.

Hipólito da Costa, o lendário fundador do Correio Brasiliense, é apresentado, então, como precursor da historiografia do Jornalismo. Alfredo de Carvalho, o historiador da imprensa é qualificado como desbravador, pelo seu trabalho de revisão de fontes e de preservação da memória da imprensa nacional no início do século 20. A personagem seguinte é o jornalista Costa Rego, figura lendária da imprensa carioca, onde foi chefe de redação do jornal Correio 
da Manhã, na década de 1940. No painel dos narradores, incluiu ainda o pesquisador Carlos Rizzini; Danton Jobim, responsável pelos estudos seminais de Jornalismo na universidade brasileira, como docente da então Universidade do Brasil, hoje Universidade Federal do Rio de Janeiro é o scholar; Luiz Beltrão, aquele que renovou o ensino do Jornalismo no Brasil; e Nelson Werneck Sodré, o intelectual inovador que escreveu a obra de síntese mais importante sobre a história da imprensa no Brasil.

A última personagem que José Marques de Melo apresenta, justamente eu, a autora desta resenha (Marialva Barbosa), ele qualificada como sendo "a sucessora". A pesquisadora, que escreveu no início do século 21 uma história cultural da imprensa brasileira, em dois volumes, para dar conta de uma análise histórica pautada nas ações humanas ao percorrer 200 anos de história da imprensa no país se viu assim instada à condição de personagem ao lado de intelectuais e jornalistas emblemáticos nessa longa história. Nessa atitude, vemos mais uma vez a benevolência do autor que procura não apenas legar o que aprendeu e ensinou para as novas gerações, mas que busca, como fez ao longo de toda uma vida, constituir sucessores.

Ao me transformar em "sucessora" de Danton Jobim (algo que de fato não sou, sendo apenas uma professora que ocupa hoje a cadeira de titular de Jornalismo da UFRJ, lugar que ele ocupou um dia) mostra, mais uma vez, o sentido maior de seu "itinerário": deixar legados e produzir emblemas narrativos em torno de personagens para os quais ele construiu afetos, algumas vezes intelectuais, outras vezes de profunda amizade. Só dessa forma posso entender figurar como a "sucessora" nesse itinerário crítico e nesse amplo e complexo mosaico conceitual de José Marques de Melo. 